Jurnal Teknik Komputer AMIK BSI

Volume 8, No.1, Januari 2022

P-ISSN 2442-2436, E-ISSN: 2550-0120

Akreditasi Ristekdikti, No: 36/E/KPT/2019 (Sinta 4)

DOI: $10.31294 /$ jtk.v4i2

\title{
Rancang Bangun Payroll System PT. Konsuil Perdana Indonesia Area Bogor
}

\author{
Artika Surniandari ${ }^{1}$, Nurma Safitri ${ }^{2}$ \\ ${ }^{1,2}$ Universitas Bina Sarana Informatika \\ 1e-mail: artika.ats@bci.ac.id \\ 2e-mail: nurmasafitri03@gmail.com
}

\begin{tabular}{ccc}
\hline Diterima & Direvisi & Disetujui \\
$24-10-2021$ & $30-12-2021$ & $13-01-2022$ \\
\hline
\end{tabular}

\begin{abstract}
Abstrak - Pemanfaatan Teknologi Informasi untuk menunjang kualitas informasi membawa dampak positif, karena untuk memperoleh informasi yang dibutuhkan perlu memperhatikan kualitas data dan proses pengolahannya. Internet juga merupakan sarana yang sangat potensial untuk melakukan kegiatan perkantoran. Berdasarkan gagasan diatas, penulis ilmiah akan membahas tentang pembuatan suatu aplikasi berbasis web sebagai penunjang dalam sistem informasi penggajian. Tujuan pembuatan web ini untuk memudahkan admin bila ingin mengelola data penggajian, selain itu dapat lebih mengefektifkan dan mengefesiensikan waktu, terutama untuk pebisnis yang biasanya tidak mempunyai waktu banyak. Metode pengembangan perangkat lunak yang digunakan adalah metode waterfall dengan PHP, HTML, MySQL, Dreamweaver sebagai software yang digunakan. PHP sendiri dipilih karena bahasanya yang bersifat scripting dan memang banyak sekali dipakai untuk membuat web karena kedinamisan dan kompleksitas dalam berbagai database. Dengan penggunaan metode waterfall ini diharapkan web dapat difungsikan dengan baik dan mendapat hasil sesuai yang diinginkan.
\end{abstract}

Kata Kunci: web, programming, payroll

Abstract - Utilization of Information Technology to support the quality of information has a positive impact, because to obtain the required information, it is necessary to pay attention to the quality of the data and the processing process. The internet is also a very potential means to carry out office activities. Based on the above ideas, scientific writers will discuss the creation of a web-based application as a support for the payroll information system. The purpose of making this website is to make it easier for admins if they want to manage payroll data, besides that it can be more effective and time efficient, especially for business people who usually don't have much time. The software development method used is the waterfall method with PHP, HTML, MySQL, Dreamweaver as the software used. PHP itself was chosen because of its scripting language and it is widely used to create web because of the dynamics and complexity in various databases. With the use of the waterfall method, it is hoped that the web can function properly and get the desired results.

Keywords: web, programming, payroll

\section{PENDAHULUAN}

Dalam dunia kerja upah atau gaji merupakan hal yang utama karena merupakan feedback yang pekerja dapatkan dari tempat kerjanya sebagai pengganti pemikiran, tenaga dan usaha yang dilakukan seorang pekerja untuk menghasilkan karya dan manfaat bagi tempat kerjanya. Namun seringkali pada saat pembayaran upah atau gaji tersebut menimbulkan komplain karena ketidak sesuaian perhitungannya atau karena sebab lain, terutama jika jenis pengolahan datanya masih http://ejournal.bsi.ac.id/ejurnal/index.php/jtk manual. Namun ada kalanya perusahaan menengah kebawah tidak menyediakan sistem yang terkomputerisasi dikarenakan jumlah karyawan yang sedikit dan dianggap mudah dalam perhitungannya sehingga tidak memerlukan sistem yang terkomputerisasi selain pertimbangan biaya pembangunan sistemnya.

"Suatu sistem dapat membantu penerapan untuk mengatur kegiatan pekerjaan di setiap perusahaan atau instansi. Penggunaan Teknologi membawa dampak yang cukup besar pada dunia industri dalam 
membuat keputusan-keputusan” (Safirah \& Masripah, 2018)

"Teknologi informatika semakin berkembang dari waktu ke waktu. Perkembangannya banyak memberikan dampak positif bagi manusia/kita dalam bidang komputerisasi. Tanpa terkecuali dengan bidang akuntansi. Pengolahan data akuntansi secara manual seperti proses yang masih menerapkan pencatatan secara tertulis, serta penggunakan Microsoft Excel 2007 dimana lebih banyak memiliki resiko kehilangan data dibandingkan dengan menggunakan sistem yang terkomputerisasi." (Utami \& Hidayat, 2018)

"Pengelolaan informasi yang cepat dan akurat di nilai sangat berguna karena dapat membantu berkembangnya sebuah instansi atau perusahaan. Salah satu bentuk implementasi sistem sistem informasi yang cepat, tepat dan akurat ini adalah sistem infomasi berbasis website yang memanfaatkan teknologi komputer dan teknologi internet."(Fitriani et al., 2018)

Menurut Rozi dan SmitDev dalam (Hidayat et al., 2017) dikemukakan bahwa "Website bisa diibaratkan sebagai sebuah rumah, toko, atau kantor. Sebuah rumah atau kantor harus memiliki alamat tetap, ada fisik bangunannya, serta ada isinya berupa ruang-ruang, peralatan, dan perabotan agar orang bisa beraktivitas di dalamnya".

Penelitian ini memiliki tujuan utama untuk mengetahui bagaimana prosedur penggajian yang dijalankan diperusahaan tersebut dan dari temuan tentang kendala yang dialami saat berjalannya sistem yang ada dengan ini memunculkan alternatif pemecahan masalah dengan pembangunan sistem ke arah komputerisasi sistem penggajian dengan menggunakan basis online dalam aplikasinya

\section{METODOLOGI PENELITIAN}

Dalam penelitian ini untuk mendapatkan datanya penelitian dilakukan dengn cara kualitatif yang terdiri dari observasi pengamatan langsung di perusahaan dengan mengamati proses sistem yang berjalan tentunya akan lebih mudah dianalisa kekurangan sistem tersebut, selain melakukan observasi untuk mendapatkan data yang dibutuhkan dilaksanakan konsultasi berupa tanya jawab dengan bagian penggajian serta untuk memenuhi kebutuhan teoritis dilaksanakan studi pustaka dengan mengumpulkan literatur, jurnal dan sejumlah bahan penelitian.
Dalam merancang perangkat lunak digunakan Model SDLC air terjun (waterfall) sebagai model untuk merancang perangkat lunak sebagai solusi permasalahan siste yang sebelumnya..

"Model Waterfall adalah model klasik yang memiliki sifat sistematis dan berurutan dalam pengembangan software. Nama model ini sebetulnya yaitu Linear Sequential Model dan sering disebut metode waterfall. Disebut metode waterfall karena tahapan yang dilalui harus menunggu selesainya pada tahapan sebelumnya dan menjadi berurutan." (Mailasari, 2019).

Dalam metode waterfall langkah yang dilaksanakan dalam merancang perangkat lunak terlebih dahulu kita mengenali sistem yang berjalan dengan cara menganalisanya untuk mendapatkan kekurangan dan masalah yang dihadapi sehingga dapat dirancang aplikasi sebagai solusi permasalahan yang ada, setelah data hasil analisa diperoleh dilanjutkan dengan mendesain rancangan kemudian melakukan penulisan koding programnya dan terakhir adalah melakukan test terhadap program yang telah dirancang.

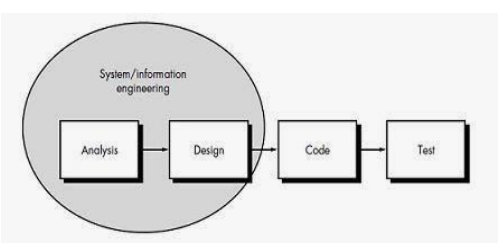

Sumber: (Sukamto \& Salahuddin, 2018)

Gambar 1. Model Waterfall

\section{HASIL DAN PEMBAHASAN}

Sebagai tahapan pertama dari metode perancangan perangkat lunak adalah tahap analisa dalam tahapan ini analisa yang dilakukan adalah menganalisa kebutuhan sistem dan kebutuhan dari pengguna. Untuk menghasilkan sebuah program yang user friendly hendaknya memperhatikan kebutuhan user diantaranya ketersediaan petunjuk dan langkah mudah dalam pengoperasiannya nanti. Sebelum menemukan kebutuhan yang tak kalah pentingnya adalah mengetahui prosedur dari sistem tersebut. Dalam sistem penggajian di PT.Konsuil Perdana Indonesia ini prosedurnya dapat digambarkan dalam activity diagram sebagai berikut : 


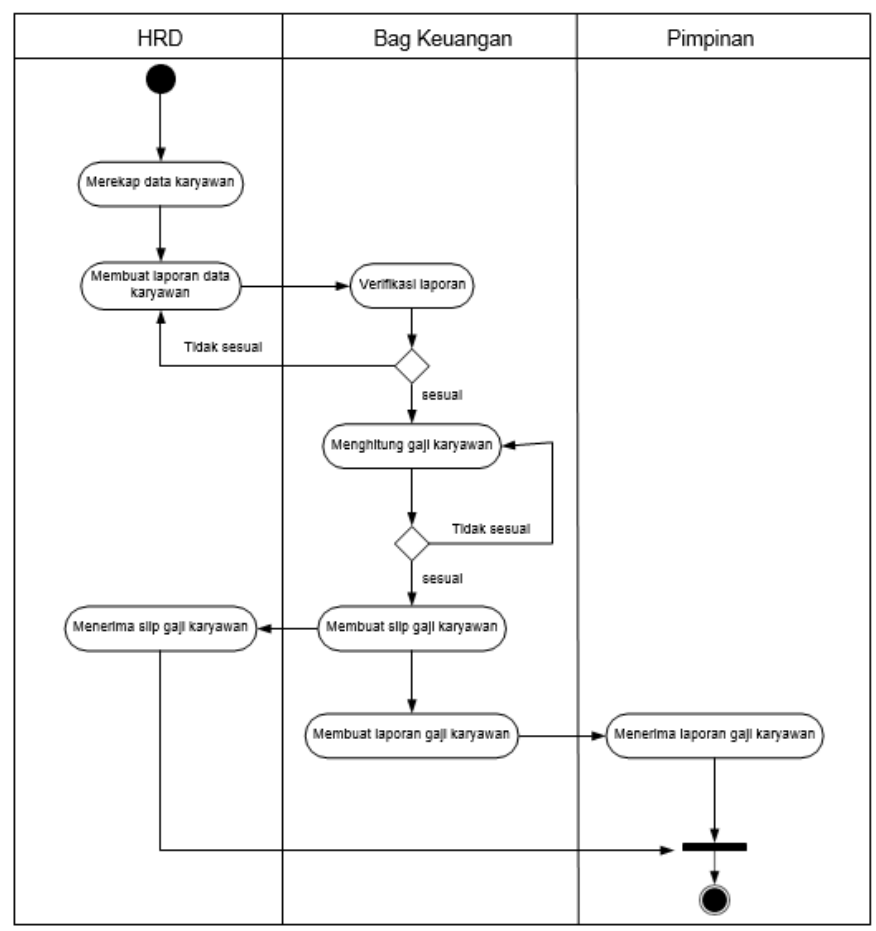

Gambar 2. Activity Diagram Sistem Payroll PT Konsuil Perdana Indonesia

Dari diagram diatas digambarkan setiap karyawan yang telah melakukan presensi kehadiran aka direkap oleh bagian HRD, berdasarkan jabatannya nantinya karyawan akan dihitung gajinya oleh bagian keuangan tunjangan akan diberikan sesuai dengan jabatan masing masing karyawan. Dai hasil perhitungan tersebut makan bagian keuangan akan membuatkan slip gajinya serta laporan penggajian setiap periode penggajian.

Dari hasil analisa tersebut maka analisa spesifikasi kebutuhan ( system requirement ) dari sistem informasi pembuatan :

\section{Kebutuhan Admin}

A.1 Admin memiliki hak akses untuk dapat mengelola data karyawan

A.2 Admin memiliki hak akses untuk dapat mengelola data Jabatan

A.3 Admin memiliki hak akses untuk dapat mengelola Penggajian

A.4 Admin memiliki hak untuk dapat mengelola akun login seluruh user
2. Kebutuhan Karyawan

A.1 Karyawan memiliki hak akses untuk masuk ke form karyawan

A.2 Karyawan memiliki hak akses melihat data penggajian

Tahap selanjutnya dari perancangan perangkat lunak ini adalah tahap desain dimana dalam mebuat rancangan program berbasis web perlu dilakukan persiapan rancangan basis datanya terlebih dahulu adapun rancangan basis data dapat digambarkan dalam Entity Relationship Diagram (ERD), adapun rancangannya sebagai berikut : 


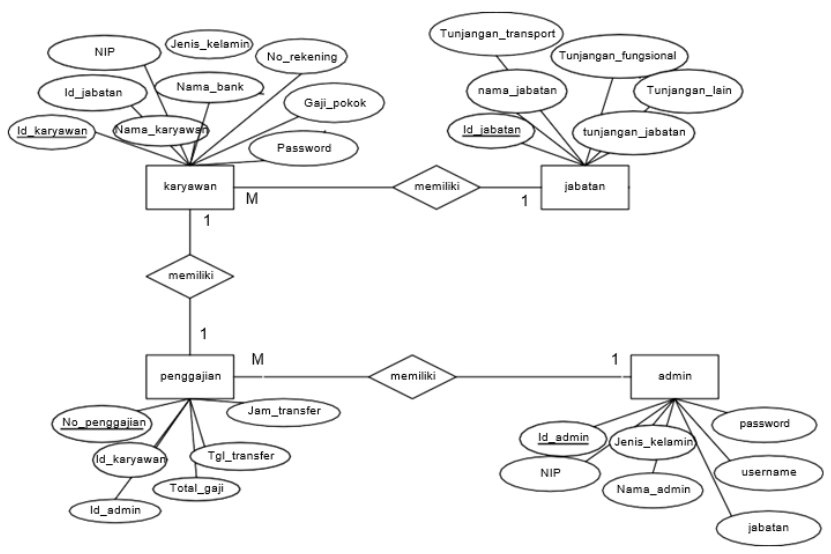

Gambar 2. Entity Relationship Diagram Program Payroll

Pada diagram diatas digambarkan bahwa program payroll berbasis web ini memiliki empat entity diantaranya entity karyawan, jabatan, admin dan penggajian yang saling terelasi.
Dari entity relationship yang terbentuk maka tabel tabel yang terbentuk dalam rancangan database sebagai berikut :

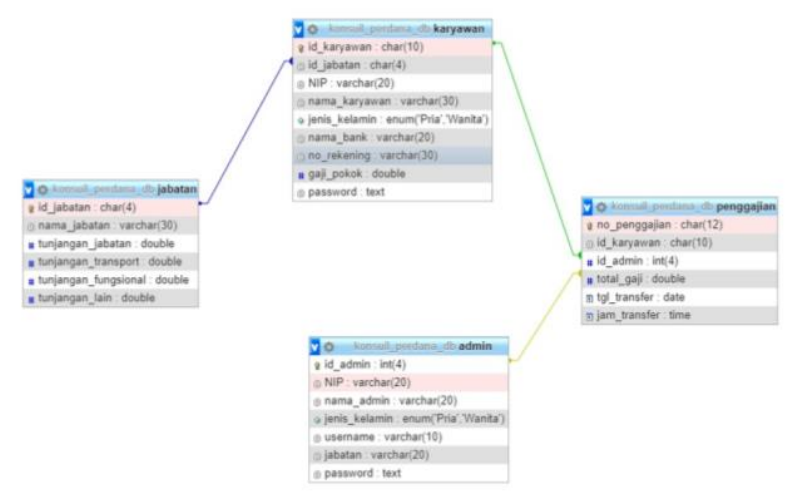

Gambar 3. Rancangan Database Payrol

Tahapan selanjutnya adalah adalah perancangan user interface dan pembuatan kode programnya dalam hal ini tampilan dari aplikasi Payroll kali ini sebagai berikut :

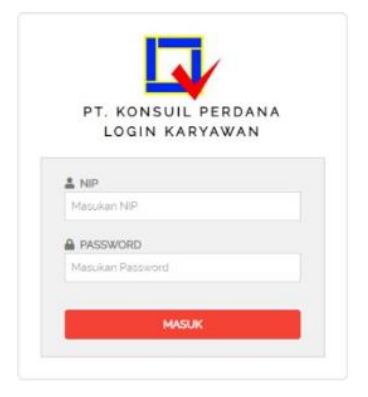

Gambar 4. Tampilan Login

Pada tampilan ini nantinya admin akan melakukan login dengan menggunakan NIP dan password yang dimiliki apabila ada kesalahan penulisan maka akan muncul pesan kesalahan apabila NIP dan Password benar maka akan masuk ke aplikasi selanjutnya

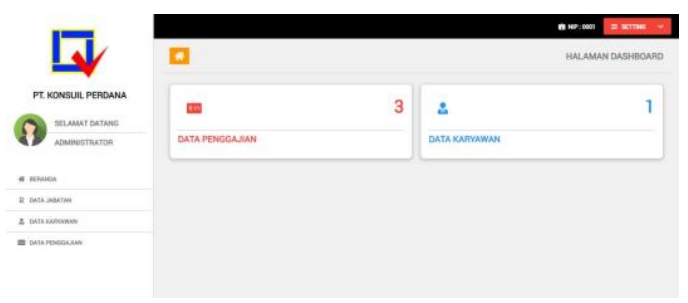

Gambar 5. Beranda Admin

Pada laman ini admin dapat mengelola data karyawan, data jabatan dan data penggajian 
Adapun bentuk rancangan tampilan data karyawan sebagai berikut :

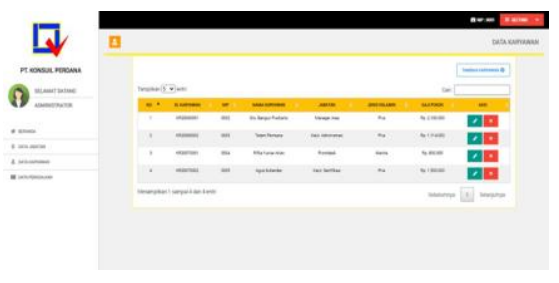

Gambar 6. Tampilan Data Karyawan

Pada tampilan diatas admin dapat mengelola data karyawan dapat dilakukan penambahan dan penghapusan data

Dan tampilan halaman penggajian sebagai berikut

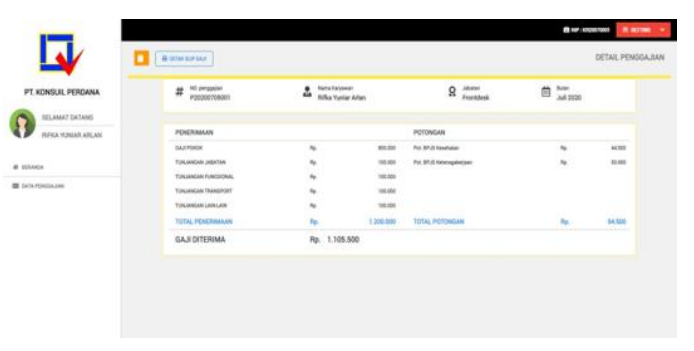

Gambar 7. Tampilan Halaman Penggajian

Sedangkan dari sisi karyawan dapat dilihat dengan tampilan sebagai berikut

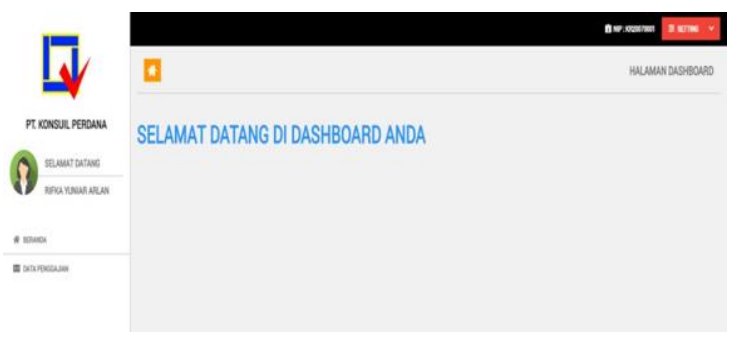

Gambar 8. Halaman Beranda Karyawan

Dari halaman beranda karyawan tersebut dapat melihat data penggajian dan detai penggajian serta mencetak slip gaji sebagai berikut :

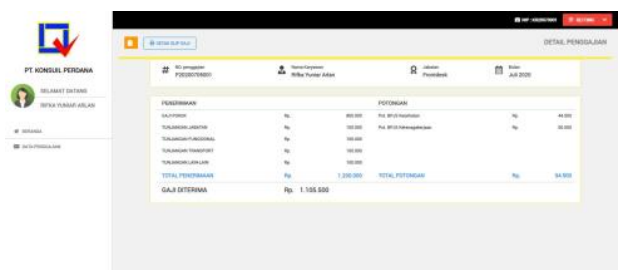

\section{Karyawan}

Pada tampilan diatas adalah beranda setelah login sebagai karyawan dan tampilan penggajian yang dapat dilihat oleh karyawan.

Langkah selanjutnya dari perancangan perangkat lunak adalah testing program, dalam hal ini digunakan pengujian menggunakan metode blackbox testing yang bertujuan menguji program yang dirancang apakah saat dijalankan masih terdapat kondisi yang tidak sesuai dan hasil yang dimunculkan sesuai dengan harapan.

Tabel 1. Hasil Pengujian Black Box Testing pada Halaman Login Admin

\begin{tabular}{|c|c|c|c|c|c|}
\hline $\begin{array}{l}\text { No } \\
\text {. }\end{array}$ & $\begin{array}{l}\text { Skenario } \\
\text { Pengujian }\end{array}$ & Test Case & $\begin{array}{l}\text { Hasil yang } \\
\text { diharapkan }\end{array}$ & $\begin{array}{l}\text { Hasil } \\
\text { Pengujian }\end{array}$ & $\begin{array}{l}\text { Kesimpul } \\
\text { an }\end{array}$ \\
\hline 1 & $\begin{array}{l}\text { Seluruh field } \\
\text { yang ada pada } \\
\text { form login tidak } \\
\text { di isi, kemudian } \\
\text { klik login. }\end{array}$ & $\begin{array}{l}\text { User name } \\
\text { : (kosong) } \\
\text { Password: } \\
\text { (kosong) }\end{array}$ & $\begin{array}{l}\text { Muncul pesan } \\
\text { kesalahan } \\
\text { "NIP tidak } \\
\text { boleh Kosong, } \\
\text { Password } \\
\text { Tidak Boleh } \\
\text { Kosong" maka } \\
\text { kembali ke } \\
\text { tampilan login }\end{array}$ & $\begin{array}{l}\text { Sesuai } \\
\text { Harapan }\end{array}$ & Valid \\
\hline 2 & $\begin{array}{l}\text { Mengetikkan } \\
\text { user name } \\
\text { danfieldyang } \\
\text { lainnyatidak di } \\
\text { isi, } \\
\text { kemudianlog in }\end{array}$ & $\begin{array}{l}\text { User name } \\
\text { : (admin) } \\
\text { Password: } \\
\text { (kosong) }\end{array}$ & $\begin{array}{l}\text { Muncul } \\
\text { menampilkan } \\
\text { pesan } \\
\text { "Password } \\
\text { Tidak Boleh } \\
\text { Kosong" }\end{array}$ & $\begin{array}{l}\text { Sesuai } \\
\text { Harapan }\end{array}$ & Valid \\
\hline 3 & $\begin{array}{l}\text { Mengetikkan } \\
\text { user name } \\
\text { danpassword } \\
\text { kemudianlog in }\end{array}$ & $\begin{array}{l}\text { User name } \\
: \text { (admin) } \\
\text { Password: } \\
\text { (admin) }\end{array}$ & $\begin{array}{l}\text { Akses masuk } \\
\text { diterima dan } \\
\text { akan } \\
\text { menampilkan } \\
\text { pesan"Login } \\
\text { Berhasil". }\end{array}$ & $\begin{array}{l}\text { Sesuai } \\
\text { Harapan }\end{array}$ & Valid \\
\hline 4 & $\begin{array}{l}\text { Mengetikkan } \\
\text { nip nama } \\
\text { karyawan } \\
\text { dan field } \\
\text { yang lainnya } \\
\text { tidak } \\
\text { di isi, }\end{array}$ & $\begin{array}{l}\text { NIP } \\
(00001), \\
\text { Nama } \\
\text { Karyaw } \\
\text { an } \\
\text { (ujang), } \\
\text { jabatan } \\
\text { (Kosong } \\
\text { ), jenis } \\
\text { kelamin } \\
\text { (Kosong } \\
\text { ), }\end{array}$ & $\begin{array}{l}\text { pesan "Maaf, } \\
\text { Jabatan, } \\
\text { jenis } \\
\text { kelamin, Gaji } \\
\text { pokok, nama } \\
\text { bank, } \\
\text { Nomor }\end{array}$ & $\begin{array}{l}\text { Sesuai } \\
\text { Harapan }\end{array}$ & Valid \\
\hline
\end{tabular}

Gambar 9. Halaman Penggajian Pada Laman 
Tabel 2. Hasil Pengujian Black Box Testing pada Halaman Tambah Datakaryawan

\begin{tabular}{|c|c|c|c|c|c|}
\hline No. & $\begin{array}{l}\text { Skenario } \\
\text { Pengujian }\end{array}$ & Test Case & $\begin{array}{l}\text { Hasil yang } \\
\text { diharapkan }\end{array}$ & $\begin{array}{l}\text { Hasil } \\
\text { Penguji } \\
\text { an }\end{array}$ & $\begin{array}{l}\text { Kesim } \\
\text { pulan }\end{array}$ \\
\hline 1 & $\begin{array}{l}\text { Seluruh field } \\
\text { yang ada } \\
\text { pada } \\
\text { formTambah } \\
\text { Data } \\
\text { karyawan } \\
\text { tidak di isi, } \\
\text { kemudian } \\
\text { klik Simpan } \\
\text { Tambah Data } \\
\text { karyawan }\end{array}$ & $\begin{array}{l}\text { NIP } \\
\text { (kosong), } \\
\text { Nama } \\
\text { Karyawan } \\
\text { (Kosong), } \\
\text { jabatan } \\
\text { (Kosong), } \\
\text { jenis kelamin } \\
\text { (Kosong), } \\
\text { Gaji pokok } \\
\text { (Kosong), } \\
\text { nama bank } \\
\text { (Kosong) } \\
\text { Nomor } \\
\text { rekening } \\
\text { (kosong) }\end{array}$ & $\begin{array}{l}\text { Sistem tidak } \\
\text { dapat } \\
\text { melanjutkan } \\
\text { dan } \\
\text { menampilkan } \\
\text { pesan "Maaf, } \\
\text { NIP } \\
\text { Nama } \\
\text { Karyawan, } \\
\text { Jabatan, } \\
\text { jenis } \\
\text { kelamin, Gaji } \\
\text { pokok, nama } \\
\text { bank, Nomor } \\
\text { rekening, } \\
\text { Masih } \\
\text { Kosong" }\end{array}$ & $\begin{array}{l}\text { Sesuai } \\
\text { Harapan }\end{array}$ & Valid \\
\hline
\end{tabular}

\section{KESIMPULAN}

Perancangan sebuah program untuk pengolahan data payroll pada suatu perusahaan tentunya diharapkan mampu menghadirkan solusi dari permasalahan yang dihadapi oleh sebuah perusahaan dan tentunya diharapkan kinerja bagian penggajian lebih efektif dan efisien, keamanan data dan kemudahan pelaporan juga diharapkan dapat menunjang jalannya sistem payroll dengan adanya payroll sistem yang terintegrasi dengan sistem pencatatan kehadiran tentunya akan memudahkan proses perhitungan gaji nantinya.

\section{REFERENSI}

Fitriani, E., Firmansyah, D., Aryanti, R., \& Walim, W. (2018). Implementasi Model Waterfall Pada Sistem Informasi Akademik Berbasis Web Pada Smk Pertanian Karawang. Jurnal Techno Nusa Mandiri, 15(2), 137. https://doi.org/10.33480/techno.v15i2.923

Hidayat, R., Marlina, S., \& Utami, L. D. (2017). Perancangan Sistem Informasi Penjualan Barang Hanmade Berbasis Website dengan Metode Waterfall.

Mailasari, M. (2019). Sistem Informasi Perpustakaan Menggunakan Metode Waterfall. Jurnal Sisfokom (Sistem Informasi Dan Komputer), $8(2)$, https://doi.org/10.32736/sisfokom.v8i2.657

Safirah, S., \& Masripah, S. (2018). Penerapan Aplikasi Akuntansi Pada Laporan Keuangan Peusahaan Dagang. Perspektif, XVI(2), 149-154.

Sukamto, R. A., \& Salahuddin, M. (2018). Perancangan Perangkat Lunak. Informatika Bandung.

Utami, L., \& Hidayat, R. (2018). Pengolahan Data Keuangan Dengan Menggunakan Zahir Accounting 5. 1. Perspektif, XVI(1), 99-106. 